\title{
Changing of Uric Acid Levels by Age and Sex in Patients with Diabetes Mellitus
}

\author{
Nilgün Basaran', Osman Evliyaoglul, Veysel Sucul, Okan Dikker', Leyla Bulut ${ }^{l}$, Fatma Tezcan², \\ Vesile Kalaslıoğlul, Rıza Sandıkçıl, Müberra Vardar ${ }^{l}$
}

\begin{abstract}
Objective: We examined the association between uric acid and glycemic status by the aspects of age and sex.

Methods: The retrospective was performed study at Okmeydanı Educate and Research Hospital. All data were obtained from the patient records. Only one sample of $\mathrm{HbA} 1 \mathrm{c}$ or glucose measurement within a year was included. To evaluate the pattern of glucose control, we categorized the patients according to $\mathrm{HbA1c}$ levels and grouped them according to a range of values. $\mathrm{HbA} 1 \mathrm{c}$ was measured by high performance liquid chromatography, routine biochemistry parameters were determined by photometric method.
\end{abstract}

Results: Serum uric acid levels showed an increasing trend with the age in female group and this trend became significant after 30 years old $(p<0.001)$. The significant effect of $\mathrm{HbA} 1 \mathrm{c}$ and gender on uric acid levels were determined in the subjects having no renal failure. There was a significant increase of uric acid levels in prediabetics than normal group and decrease in unregulated diabetics. But in both sex groups the pattern of changing was different.

Conclusion: In conclusion, we found that age is an important factor examining the serum uric acid levels of female subjects. The peak values of serum uric acid were detected in prediabetic group in males but in females this peak point was diabetic group. J Clin Exp Invest 2016; 7 (1): 1-6

Key words: Diabetes mellitus, uric acid, age, gender

\section{Diyabetes Mellitus'lu Hastalarda Ürik Asit Seviyelerinin Yaş ve Cinsiyetle Değişimi}

\section{ÖZET}

Amaç: Çalışmamızda yaş ve cinsiyeti göz önüne alarak diyabetli hastaların glisemik durumu ile ürik asit seviyelerinin ilişkisi araştıııldı.

Yöntemler: Çalışma Okmeydanı eğitim araştırma hastanesinde retrospektif olarak yapıldı, Hasta kayıtlarından sonuçlara ulaşıldı. Hastaların bir yıl içindeki tek HbA1c veya glukoz ölçümü çalışmaya dahil edildi. Glukoz kontrolünü belirlemek için hastalar HbA1c seviyelerine göre sınıflandırıldı. Rutin biyokimya parametreleri fotometre ile çalışıırken, HbA1c HPLC ile çalışıldı.

Bulgular: Kadın grubunda ( $p$ <.001) ürik asit düzeylerinin yaşla birlikte arttığı ve bu artışın 30 yaşından sonra anlamlı hale geldiği bulundu. Böbrek yetmezliği olmayan hastalarda ürik asit seviyelerinin üzerine HbA1c ve cinsiyetin anlamlı bir etkisi saptandı. Ürik asit seviyelerinin prediyabetik hastalarda yükselirken kontrolsüz diyabetiklerde azaldığı saptandı. Bu azalma paterni cinsiyete göre farklılık gösterdi.

Sonuç: Sonuç olarak, kadınlarda ürik asit seviyelerini değerlendirirken yaşın önemli bir faktör olduğu kanısına varıldı. Ayrıca erkeklerde prediyabetik grupta serum ürik asit seviyeleri pik yaparken, kadınlardaki pik diyabetik grupta gözlendi.

Anahtar kelimeler: Diabetes mellitus, ürik asit, yaş, cinsiyet

\section{INTRODUCTION}

Uric acid (UA) is final breakdown product of purine metabolism and is one of the first line antioxidant defense mechanism in the plasma with the roles of pow- erful scavenger of single oxygen peroxyl (ROS) and hydroxyl $(\mathrm{OH})$ radicals $[1,2]$. In spite of the antioxidant activity in the extracellular environment, UA has harmful results once it enters vascular smooth muscle cells and adipocytes [3]. Its effects are inhibition of

\footnotetext{
${ }^{1}$ Department of Biochemistry, Okmeydanı Training and Research Hospital, Istanbul, Turkey

${ }^{2}$ Department of Internal Diseases, Okmeydanı Training and Research Hospital, Istanbul, Turkey
}

Correspondence: Osman Evliyaoglu,

Department of Biochemistry, Okmeydanı Training and Research Hospital, Istanbul, Turkey Email: oevliya@hotmail.com

Received: 04.12.2015, Accepted: 13.01.2016

Copyright @ JCEI / Journal of Clinical and Experimental Investigations 2016, All rights reserved 
endothelial function [4], induction of platelet aggregation [5], and chronic systemic inflammation [6].

Hyperuricemia is described as high levels of UA in the plasma (serum urate $>7 / 6 \mathrm{mg} / \mathrm{dL}$, male/female respectively) and is derived from increased production or decreased excretion [7]. Studies have shown that the hyperuricemia associated with many diseases such as; arterial hypertension [8], cardiovascular risks [9], metabolic syndrome [10]. However, the relationship between diabetes mellitus and hyperuricemia is still not well defined. Some genes associated such as the SLC2A9 gene [encodes uric acid and glocose transporter] [11] and Uric acid-associated genes have an impact on the risk of T2D, glucose metabolism, insulin secretion and metabolic syndrome $[12,13]$. Additionally to genetic findings some studies have emphasized that elevated serum uric acid [SUA] levels are positively associated with the development of type 2 diabetes itself [17], impaired fasting glucose [18] and 2-hour postload glucose [19]. Elevated SUA stated as an independent predictor of vascular complications and mortality in type 2 diabetes mellitus patients [14] and is associated with excess risk for development of the disease $[15,16]$. Despite these associations some limitations to use SUA as an indicator can be counted. First, antioxidative characteristic of UA showed paradoxical value depending on blood concentration [20]. Second, SUA concentration differed with sex [21]. Third, age may affect SUA levels but this parameter is not well documented in the literature. We planned the study to evaluate the association between SUA and glycemic status by the aspects of age and gender.

\section{METHODS}

We performed the retrospective study on a consecutive series of outpatients who were followed up at Okmeydani Educational and Research Hospital for 1 year. All data were obtained from the patient records. Only one sample of HbA1c or glucose measurement within a year was included. If there were multiple measurements for a patient within a year, the most recent measurement was selected. Patients were excluded if they had liver disease, myocardial infarction, heart failure and kidney disease except renal failure. To evaluate the pattern of glucose control, we categorized the patients according to $\mathrm{HbAlc}$ levels and grouped them according to a range of values. Cut-off levels of patients were evaluated as $6.5 \%$ according to The American Association of Clinical Endocrinologists [22]. Group I (3.3-5.6\% HbA1c) were accepted as the control group. HbA1c levels above the laboratory 'normal' range, but below the diagnostic cut-point for diabetes $(5.7-6.4 \%)$, are categorized as prediabetes and stated as group 2 [23]. Diabetic group was named as Group 3 where unregulated diabetics was Group 4 and worse regulated diabetics was Group 4. Venous blood samples were drawn after $12 \mathrm{~h}$ of overnight fasting. $\mathrm{HbAl} \mathrm{c}$ was measured by high performance liquid chromatography (Premier Hb9210, Primus Diagnostics, a Trinity Biotech Company, Kansas City, USA). Routine biochemistry parameters were determined by photometric method (Cobas 8000, c702, Roche Diagnostics GmbH, Mannheim, Germany).

\section{Statistical analysis}

All the data were collected in a computerized database for statistical analyses. Normality of the distributions of all continuous variables was tested by the Kolmogorov-Smirnov test. ANOVA test was used to assess the statistical significance of differences among groups and ANCOVA was used for covariance analysis. The Pearson and Spearman correlation test was used to determine the correlations between parameters in each group. The SPSS 18.0 computer program was used for analysis. A p value less than 0.05 was accepted as significant.

\section{RESULTS}

We divided the study into two groups according to the renal failure existence, descriptive of groups stated in Table 1. Univariate general linear model of parameters showed in Table 2 . There was significant effect of age on UA levels in whole group $(\mathrm{p}<0.001)$. Then the study group categorized according to age (Table 3 ). In females there was an increasing trend between the groups (Figure1) and the difference between groups were significant after 30 years old (Table 3 ), but in males the difference among groups become significant after 80 years old $(\mathrm{p}<0.05)$ (Figure1).

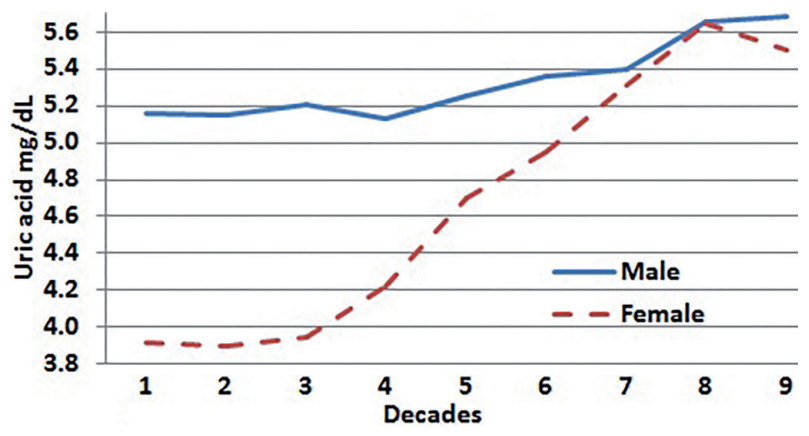

Figure 1. Uric acid levels of age groups in male and female subjects 
The significant effect of $\mathrm{HbAlc}$ and gender on UA levels were determined in the subjects having no renal failure (Table 1). Then the group without renal failure categorized according to the $\% \mathrm{HbAlc}$ levels (Table 4) and layered by the sex. There was a significant increase of UA levels in prediabetics than normal group and decrease in unregulated diabetics (Figure 2 ). But in both sex groups the pattern of changing were different; in males top of the increasing point was prediabetics group, in females it was diabetics group (Figure 2) and the difference between groups were significant (Table 4).

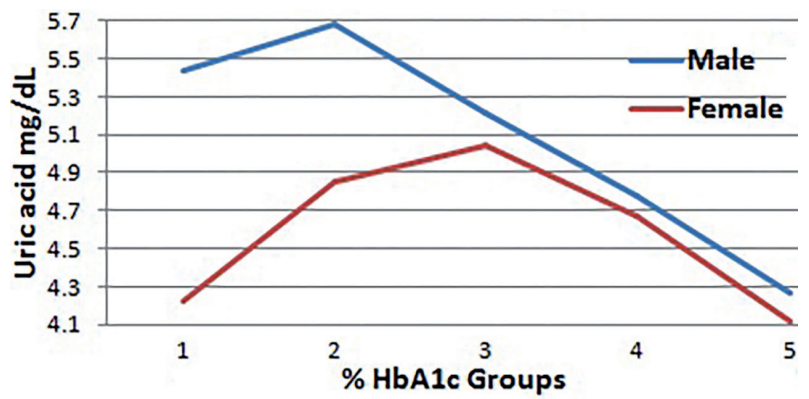

Figure 2. Uric acid levels \%HbA1c groups in male and female subjects
Table 1. Descriptive data of study groups according to the renal failure existence

\begin{tabular}{|c|c|c|c|c|c|c|}
\hline & & $\mathbf{n}$ & Minimum & Maximum & Mean & SD \\
\hline \multirow{6}{*}{$\begin{array}{l}\text { Subjects without } \\
\text { renal failure }\end{array}$} & Age (Year) & 19805 & 10 & 99 & 53.21 & 15.42 \\
\hline & Uric Acid (mg/dL) & 19805 & 1 & 16.6 & 4.839 & 1.4384 \\
\hline & Creatinine (mg/dL) & 19805 & 0.14 & 1.2 & 0.7658 & 0.17013 \\
\hline & Glucose (mg/dL) & 19805 & 49 & 669 & 123.08 & 64.161 \\
\hline & HbA1c (\%) & 19805 & 3.2 & 18.4 & 6.768 & 1.9172 \\
\hline & Sex (Female/Male) & & & 13036 / 6769 & & \\
\hline \multirow{6}{*}{$\begin{array}{l}\text { Subjects with } \\
\text { renal failure }\end{array}$} & Age (Year) & 2498 & 16 & 99 & 68.26 & 12.762 \\
\hline & Uric Acid (mg/dL) & 2498 & 1.4 & 23 & 7.34 & 2.3956 \\
\hline & Creatinine (mg/dL) & 2498 & 1.21 & 20.88 & 2.2975 & 1.81794 \\
\hline & Glucose (mg/dL) & 2498 & 49 & 598 & 134.812 & 75.3267 \\
\hline & HbA1c (\%) & 2498 & 4 & 18.3 & 7.03 & 1.9077 \\
\hline & Sex (Female/Male) & \multicolumn{2}{|c|}{$1033 / 1465$} & & & \\
\hline
\end{tabular}

Table 2. Univariate general linear model of parameters

\begin{tabular}{|c|c|c|c|c|}
\hline \multicolumn{5}{|c|}{ Tests of Between-Subjects Effects } \\
\hline \multirow{2}{*}{ ANOVA of Uric Acid } & \multicolumn{2}{|c|}{ Subjects without renal failure } & \multicolumn{2}{|c|}{ Subjects with renal failure } \\
\hline & $\mathbf{F}$ & Sig. & $\mathbf{F}$ & Sig. \\
\hline Corrected Model & 95.954 & $<0.001$ & 2.216 & $<0.001$ \\
\hline Intercept & 86.851 & $<0.001$ & 8.254 & 0.004 \\
\hline Age (Year) & 9.671 & .002 & 7.314 & 0.007 \\
\hline HbA1c (\%) & 6.543 & .011 & 0.266 & 0.606 \\
\hline Glucose (mg/dL) & 52.036 & $<0.001$ & 1.808 & 0.179 \\
\hline Sex (Female/Male) & 0.001 & 0.974 & 1.376 & 0.241 \\
\hline Age groups & 3.262 & .001 & 0.976 & 0.453 \\
\hline HbA1c groups & 12.205 & $<0.001$ & 1.805 & 0.125 \\
\hline Sex *Age groups & 13.934 & $<0.001$ & 1.258 & 0.261 \\
\hline Sex* Hb groups & 13.397 & $<0.001$ & 1.050 & 0.380 \\
\hline Age groups $* \mathrm{Hb}$ groups & 1.870 & 0.003 & 0.915 & 0.587 \\
\hline Sex $*$ Age groups $*$ Hb groups & 0.581 & 0.964 & 1.286 & 0.167 \\
\hline
\end{tabular}

*: between 
Table3. Study groups according to the age

\begin{tabular}{ccccccc}
\hline Groups / & \multicolumn{3}{c}{ Age (year) } & \multicolumn{2}{c}{ Uric Acid } \\
\cline { 2 - 7 } Decades & $\mathbf{n}$ & Mean \pm SD & Minimum & Maximum & $\begin{array}{c}\text { Uric acid } \\
\text { levels (mg/dL) }\end{array}$ & $\begin{array}{c}\text { Comparing with } \\
\text { previous group }\end{array}$ \\
\hline 1 & 357 & $17 \pm 2$ & 10 & 19 & $4.4 \pm 1.3$ & NS \\
\hline 2 & 1213 & $25 \pm 3$ & 20 & 29 & $4.3 \pm 1.4$ & 0.995 \\
3 & 2156 & $35 \pm 3$ & 30 & 39 & $4.4 \pm 1.4$ & 0.297 \\
4 & 4132 & $45 \pm 3$ & 40 & 49 & $4.6 \pm 1.5$ & 0.002 \\
5 & 5635 & $55 \pm 3$ & 50 & 59 & $5.0 \pm 1.5$ & $<0.001$ \\
6 & 4670 & $64 \pm 3$ & 60 & 69 & $5.4 \pm 1.7$ & $<0.001$ \\
7 & 2739 & $74 \pm 3$ & 70 & 79 & $5.9 \pm 2.0$ & $<0.001$ \\
8 & 1307 & $83 \pm 2$ & 80 & 89 & $6.4 \pm 2.3$ & $<0.001$ \\
9 & 94 & $92 \pm 2$ & 90 & 99 & $6.6 \pm 2.7$ & 0.962 \\
\hline
\end{tabular}

SD: Standard deviation, NS: Not significant

Table 4. Groups according to $\mathrm{HbA} 1 \mathrm{c} \%$ levels

\begin{tabular}{lllllllll}
\hline & \multicolumn{9}{c}{ \%HbA1c } & \multicolumn{2}{c}{ Uric Acid } \\
\cline { 2 - 9 } & No & $\mathbf{n}$ & Mean \pm SD & Min & Max & $\begin{array}{l}\text { Uric acid } \\
\text { levels (mg/dL) }\end{array}$ & $\begin{array}{l}\text { Comparing with } \\
\text { prediabetics (p) }\end{array}$ & $\begin{array}{l}\text { Comparing with } \\
\text { diabetics(p) }\end{array}$ \\
\hline Normal & 1 & 6816 & $5.3 \pm 0.3$ & 3.2 & 5.6 & $4.6 \pm 1.4$ & $<0.001$ & $<0.001$ \\
Prediabetics & 2 & 7110 & $6.0 \pm 0.3$ & 5.7 & 6.6 & $5.1 \pm 1.4$ & NS & 0.988 \\
Regulated Diabetics & 3 & 4128 & $7.3 \pm 0.4$ & 6.7 & 8.0 & $5.1 \pm 1.4$ & 0.988 & NS \\
Unregulated Diabetics & 4 & 2463 & $8.8 \pm 0.5$ & 8.1 & 9.9 & $4.7 \pm 1.4$ & $<0.001$ & $<0.001$ \\
Poor Regulated Diabetics & 5 & 1786 & $11.8 \pm 1.5$ & 10.0 & 18.4 & $4.2 \pm 1.4$ & $<0.001$ & $<0.001$ \\
\hline
\end{tabular}

Min: Minimum, Max: maximum, SD: Standard deviation, NS: Not significant

\section{DISCUSSION}

Several studies have reported hyperuricemia as a risk factor for development of diabetes mellitus, especially in the context of insulin resistance; others have suggested that patients with recently diagnosed diabetes tend to have lower SUA than prediabetic or normoglycemic ones. In both statements, it may seem contradictory, but in fact the main problem is complexity of pathophysiology of UA. Insulin resistance and impaired insulin secretion are strongly influenced by UA levels [24] and may contribute to the development of hyperuricemia [25]. This was also observed in our study (Figure1), but increasing in UA levels differed according to the gender (Figure 1). UA increase in males maintained until prediabetic group and began to decrease in diabetic group. In females increasing of UA levels showed persistence in diabetes group until the glucose regulation is broken. It is important because these increases were found to be statistically significant (Figure 2). Therefore, we can say some hormones may play a role in the increase of SUA levels other than regulate glucose metabolism.
There were no significant SUA levels change between $\mathrm{HbA} 1 \mathrm{c}$ groups in patients with renal failure. We could say kidney would be the target organ in UA regulation (Table 2). Some studies stated that participants who were prediabetic or diabetic but without glycosuria had a similarly elevated prevalence of hyperuricemia. In contrast, diabetic patients with glycosuria had a null prevalence of hyperuricemia and excreted more UA and Sodium than diabetic subjects without glycosuria [26]. In our study, we found that UA levels significantly reduced in both sex in an unregulated diabetic group which are speculated by losing UA with glucose (Table 4). The findings can be explained by enhanced proximal tubule reabsorption early in the course of dysglycemia that decreases with the ensuing glycosuria at the late stage of the disorder in females. But in males this statement need some additional explanations.

Recent evidence has emerged from several large epidemiological studies indicating that SUA levels are an independent risk factor and predictor of T2D, with a $17 \%$ increment in the risk of T2D per $1 \mathrm{mg} / \mathrm{dl}$ increase in SUA levels [17]. We have observed that SUA 
levels may be early warning system with $\mathrm{HbA} 1 \mathrm{c}$ when evaluating prediabetic patients (Figure 2).

We found that SUA levels increased with age in females (Figure 1), and there was no significant difference in males (Figure 1). This increase has become significant after the age of 40 between each decade (Table 3) Therefore it can be stated that SUA levels may give important clues with $\mathrm{HbAlc}$ levels while monitoring prediabetic females older than 40 years old.

The present study had several limitations. First, this was a retrospective observational study carried out in a single institution. Secondly, the artificial conversion between serum creatinine values obtained in different periods was a limitation. Thirdly the exclusion criteria could not strictly controlled because of huge size of the working group.

In conclusion, we found that age is an important factor in differences of SUA levels between female subjects. The peak values of SUA were detected in prediabetic group of males but in females diabetic group showed the same peak values.

Declaration of Conflicting Interests: The authors declare that they have no conflict of interest.

Financial Disclosure: No financial support was received.

\section{REFRENCES}

1. Sautin YY, Nakagawa T, Zharikov S, Johnson RJ. Adverse effects of the classic antioxidant uric acid in adipocytes: NADPH oxidase-mediated oxidative/nitrosative stress. Am J Physiol Cell Physiol 2007;293:584-596.

2. Souza-Junior T, Lorenço-Lima L, Ganini D, et al. Delayed uric Acid accumulation in plasma provides additional antioxidant protection against iron-triggered oxidative stress after a Wingate test. Biol Sport 2014;31:271-276.

3. Corry DB, Eslami P, Yamamoto K, et al. Uric acid stimulates vascular smooth muscle cell proliferation and oxidative stress via the vascular renin-angiotensin system. J Hypertens 2008;26:269-275.

4. Oberbach A, Neuhaus J, Jehmlich N, et al. A global proteome approach in uric acid stimulated human aortic endothelial cells revealed regulation of multiple major cellular pathways. Int J Cardiol 2014;176:746-752.

5. Verdoia M, Barbieri L, Schaffer A, et al. Novara Atherosclerosis Study Group (NAS). Impact of diabetes on uric acid and its relationship with the extent of coronary artery disease and platelet aggregation: a single-centre cohort study. Metabolism 2014;63:640-646.

6. Kang DH, Park SK, Lee IK, Johnson RJ. Uric acid-induced $\mathrm{C}$-reactive protein expression: implication on cell prolifera- tion and nitric oxide production of human vascular cells. J Am Soc Nephrol 2005;16:3553-3562.

7. Yamamoto T. Definition and classification of hyperuricemia Nihon Rinsho 2008;66:636-640.

8. Wang SF, Shu L, Wang S, et al. Gender difference in the association of hyperuricemia with hypertension in a middleaged Chinese population. Blood Press 2014;23:339-344.

9. Bian S, Guo H, Ye P, et al. Serum uric Acid level and diverse impacts on regional arterial stiffness and wave reflection. Iran J Public Health 2012;41:33-41.

10. Lee YJ, Cho S, Kim SR. A possible role of serum uric acid as a marker of metabolic syndrome. Intern Med J 2014;44:1210-1216.

11. Liu WC, Hung CC, Chen SC, et al. The rs 1014290 polymorphism of the SLC2A9 gene is associated with type 2 diabetes mellitus in Han Chinese. Exp Diabetes Res 2011;527520:1-6.

12. Sun $X$, Zhang R, Jiang F, et al. Common variants related to serum uric Acid concentrations are associated with glucose metabolism and insulin secretion in a chinese population. PLoS One 2015;10:116714.

13. DeBosch BJ, Kluth O, Fujiwara H, et al. Early-onset metabolic syndrome in mice lacking the intestinal uric acid transporter SLC2A9. Nat Commun $2014 ; 5: 4642$.

14. Xu Y, Zhu J, Gao L, et al. Hyperuricemia as an independent predictor of vascular complications and mortality in type 2 diabetes patients: a meta-analysis. PLoS One. 2013;8:78206.

15. Krishnan E, Pandya BJ, Chung L, et al. Hyperuricemia in young adults and risk of insulin resistance, prediabetes, and diabetes: a 15-year follow-up study. Am J Epidemiol 2012;176:108-116.

16.Bhole V, Choi JW, Kim SW, et al., Serum uric acid levels and the risk of type 2 diabetes: a prospective study. Am J Med 2010;123:957-961.

17. Kodama S, Saito K, Yachi Y, et al. Association between serum uric acid and development of type 2 diabetes. Diabetes Care 2009;32:1737-1742.

18. Jia Z, Zhang X, Kang S, Wu Y. Serum uric acid levels and incidence of impaired fasting glucose and type 2 diabetes mellitus: a meta-analysis of cohort studies. Diabetes Res Clin Pract 2013;101:88-96.

19. Fan HQ, Tang W, Wang ZX, et al. Association of serum uric acid with 2-hour postload glucose in Chinese with impaired fasting plasma glucose and/or HbA1c. PLoS One 2013;8:67759.

20. Lippi G, Montagnana M, Franchini M, et al. The paradoxical relationship between serum uric acid and cardiovascular disease. Clin Chim Acta 2008;392:1-7.

21. Sumino H, Ichikawa S, Kanda T, et al. Reduction of serum uric acid by hormone replacement therapy in postmenopausal women with hyperuricaemia. Lancet 1999;354:650.

22. Lebovitz HE, Austin MM, Blonde L, et al. ACE/AACE Diabetes Road Map Task Force. Road maps to achieve glycemic control in type 2 diabetes mellitus: ACE/AACE Diabetes Road Map Task Force. Endocr Pract 2007;13:260-268. 
23. American Diabetes Association. Standards of Medical Care in Diabetes. Diabetes Care 2010; 33(Suppl 1):S11-S61.

24. Ishizaka N, Ishizaka Y, Toda E, et al. Association between serum uric acid, metabolic syndrome, and carotid atherosclerosis in Japanese individuals. Arterioscler Thromb Vasc Biol 2005;25:1038-1044
25. Nakamura K, Sakurai M, Miura K, et al. HOMA-IR and the risk of hyperuricemia: a prospective study in non-diabetic Japanese men. Diabetes Res Clin Pract 2014;106:154-160.

26. Andrade JA, Kang HC, Greffin S, et al. Serum uric acid and disorders of glucose metabolism: the role of glycosuria. Braz J Med Biol Res 2014;47:917-923. 